\title{
The Green Revolution: Socioeconomic Insecurity and Agricultural Displacement in India
}

\author{
Mia Biasucci
}

\begin{abstract}
This article discusses the Green Revolution, ostensibly implemented to address food insecurity in India. Instead, it deepened transitory food insecurity as well as systematically compounded exploitative systems of labour, landholding and capital distribution to the detriment of peasant and landless agriculturalists. The project increased the economic risk of agricultural labour and the instability of the sector as a whole. For these reasons, issues surrounding the impact of the Green Revolution inherently involve economic, social and ecological displacement and migration to urban and food-surplus areas. $A$ secondary displacement effect involved the impact of the Green Revolution on forests. Irrigation to support it required dams and canals that displaced people outside the marketoriented agricultural sector. The Green Revolution is thus shown to have had both primary and secondary displacement effects.

\section{Précis}

Le présent article aborde la question de la Révolution Verte, mise en place en grande pompe pour faire face à l'insécurité alimentaire en Inde. Contrairement aux attentes, la Révolution Verte a accentué la dépendance envers les sources alimentaires de transition. Elle a de plus servi à étroitement fusionner entre eux les éléments du système d'exploitation de la force de travail, de la propriété foncière et de la distribution des capitaux, et ce au détriment des paysans et des travailleurs agricoles sans terre. Le projet a accentué la précarité économique des travailleurs agricoles et a perpétué l'instabilité économique de la totalitédu

Mia Biasucci is Graduate Student, Faculty of Environmental Studies, York University, Toronto. secteur. Pour ces raisons, il s'avère que les questions concernant l'impact de la Révolution Verte sont inséparables du probleme des déplacements de populations à motifs économiques, sociaux ou écologiques, et de la migration vers les zones urbaines et les zones détentrices desurplus alimentaires. Un second type d'effet de ces déplacements concerne l'impact de la Révolution Verte sur les forêts. En effet, l'irrigation visant à servir de support à cette entreprise a nécessité la mise en place d'un ensemble de barrages et de canaux qui ont causé le déplacement des populations à l'extérieur de la zone agricole exploitable commercialement. Il est démontré ici que la Révolution Verte a des effets à la fois immédiats et secondaires sur le déplacement des populations.

\section{Introduction}

Throughout the relatively short life span of international development, theorists and practitioners alike have extolled its economic, political and social virtues. More recently, however, development theory and praxis have been criticized as being socially polarizing on both global and local levels, technologically inappropriate, imperialistic, and, specifically within the Indian context, causing himsa, or violence (Alvares 1994, Shiva 1991). The Indian subcontinent has been historically plagued with both chronic and transitory forms of food insecurity. Although these conditions are most often attributed to droughts and the highly variable monsoon season, development has also played a significant role. The Green Revolution was ostensibly implemented to address this insecurity; however, it instead deepened food insecurity as well as systematically compounded exploitative systems of labour, landholding and capital distribution to the detriment of peasant and landless agricul- turalists. The project increased the economic risk to cultivators and the instability of the sector as a whole. Part of the impact of the Green Revolution is economic, social and ecological displacement and migration to urban and food-surplus areas. A secondary displacement effect of the Green Revolution resulted from its irrigation dams and canals; they displaced people outside the market-oriented agricultural sector. These two displacement effects will be discussed in turn.

\section{The Green Revolution in India}

The Green Revolution is the acknowledged favourite child of the second development decade (1960s), celebrating the progress of genetic technologies and Western science. The period is also demarcated by support for neo-Malthusian ideology and the emergent concept of food security, focusing on the interrelationship between food and population. According to the World Bank, the Green Revolution is considered to be "the most widely and rapidly adopted technology in agricultural history" (Byres and Crow 1988, 163). By concentrating on the broad agricultural bases of Southern nations, the project aimed to increase (particular) crop yields in order to also increase export earnings. Tacitly it thereby incorporated a greater number of agriculturalists into the global commercialization of agriculture.

In India, the Green Revolution was driven by three main factors. First, India's status as a relatively newly independent country heightened the drive for national food self-sufficiency through a fuller market integration of agriculture. Food production has long been regarded as the "Achilles heel" of India. The feudal history of zamindars and jagirdars (landlords) persisted into the post-colonial period in various incarnations, and gross inequities in

Refuge, Vol. 16, No. 3 (August 1997) 
landholding and labour relations continued to characterize the agricultural sector. Attempts at reforms tended to replace established community support systems, such as sharecropping, with national market-oriented redistribution schemes and were largely unsuccessful. Second, and related to the latter point, the classification of India as a food-deficit nation in the mid-1960s indicated the failure of the (stagnating) agricultural sector in meeting the needs of the populace, demonstrated by widespread hunger as well as acute famines in the eastern provinces. American involvement in India is the third factor that drove the Green Revolution. The food aid required during this period was mainly supplied by the United States as part of an aid package, which concurrently stipulated the deepening of American presence within the agricultural capital market. The receipt of American aid was also predicated upon the Indian government's lifting of nationwide price ceilings on privately produced fertilizer for a period of seven years. This supported the increased presence of U.S. multinational chemical fertilizer companies in the Indian market. Thus, emergent agricultural constraints, coupled with the government's acknowledged priority regarding food self-sufficiency, led to the Green Revolution-supposedly to develop Indian agriculture, but also to pander to American corporate interests (ibid., 1988).

\section{The Green Revolution and Poor Agriculturalists}

The theoretical scale-neutrality of the project appeared ideal for the highly fragmented landholdings of the Indian countryside. The high-yielding variety (HYV) seeds were to produce substantial productivity gains independent of the size of the plot to be cultivated. However, such yields were predicated upon the ability of farmers to purchase necessary chemical fertilizers and pesticides (as the new seeds were not as hardy as the traditionally cultivated strains), in addition to their access to intensive irrigation. Although the In- dian government implemented subsidies on fertilizers and pesticides, as well as invested in substantial irrigation projects, access to these means of production was far from equitable.

The emphasis on expensive but necessary biomechanical methods practically excluded small peasant farmers. Large and medium peasant farmers were able to accommodate the cost, whereas the small peasant farmer was generally forced to buy on credit or not at all. The increased yields lowered the price of HYV crops on the market, making it impossible for the small farmer to repay loans as well as reinvest money capital into the next season's seeds, fertilizers and pesticides.

The HYVs were developed without concern for economic, social, and, least of all, ecological context. The cultivation of HYVs was tremendously dependent on scale-not necessarily the physical amount of land that one owned, but the amount of resources which could be diverted to invest in the Green Revolution. The ability to do so was the crucial factor in determining who benefited. If we use this as a point of departure to vulnerability to hunger and economic instability, then we can see that it is the poor farmer who bore the brunt of inequitable production and distribution, and thus was most susceptible to becoming increasingly impoverished and to experiencing socioeconomic crises. The main point that this article aims to make here is that impoverishment effectively limits prevention of such crises or recovery from them (Anderson and Woodrow 1993, 134).

Although the relevant literature offers many statistics supporting the Green Revolution's positive effect upon the net output of food production in India, it is critical to acknowledge, first, that the risk variable of production increased substantially, and second, that the proportions of certain crops within the recorded total were altered significantly.

The unpredictability of yields, the first impact mentioned, was not only related to climatic factors, as the extension of irrigation systems in India more or less provided a reliable source of water for the HYV crops. (According to Sarma, the performance of Indian agriculture during the Green Revolution, especially regarding the more significant [wheat] yield increases in the northwestern provinces of Punjab and Haryana, was largely due to increased irrigation; it explains about $75 \%$ of the growth in crop output [Sarma 1982, 26; Mellor 1992, 42]). The new technology was dependent upon precise and timely applications of fertilizers and pesticides which would determine the ultimate failure or success of an individual farmer's harvest. The increased risk of HYV crops, coupled with the necessary capital expenditures and the levels of indebtedness among poor farmers, made this technology unattractive for the latter. For this reason, the provinces which had the largest productivity gains generally also possessed marked disparity (Mellor 1992, 45), indicating that the main engines of growth were the large and medium farmers. Also, there are dramatic high and low agricultural productivity periods, especially with regards to wheat and rice (the banner crops of the project), since the implementation of the Green Revolution (from the late 1960 s to the mid- to late 1970 s).

Secondly, during the period of the Green Revolution the "inferior" cereals mainly consumed by the poor were plagued by the onset of significant and unprecedented negative growth rates (Chattopadhyay 1991, 79). In addition, the other staple food of the poor, pulses, also registered sharp, consistent negative growth since the 1960 s. This is significant because even slight harvest deficits can provoke extensive social crises (Wijkman and Timberlake 1984, 132).

Although these variations in agricultural production were not only influenced by the Green Revolution, the most differential rates of growth occurred during that period. The technology was essentially biased towards the production of cereals, such as rice and wheat, which catered to the global market over established Indian subsistence needs. Also, there was a tech- 
nological bias towards, and remarkable growth of, the foodgrains which require substantial irrigation over "inferior" grains and pulses which can be cultivated in drier, less fertile areas. The latter actually registered negative growth in some cases (Chattopadhyay 1991, 81; Sarma 1982, 25).

\section{Market Effects and Impoverishment}

Although agricultural production of foodgrains did increase over the period of the Green Revolution overall, it is evident that the increase was not substantial enough to assure long-term food security or national self-sufficiency, let alone stabilize the agricultural labour market. It appears that the Green Revolution has remedied India's food deficit status but the surpluses which have been created are subject to uncertainty. Statistics illustrate that the post-Green Revolution period is characterized by sharp peaks and dramatic shortfalls, often within back-to-back growing seasons (Etienne 1988; Sarma 1989). According to Sarma $(1989,152)$, "exports in the agricultural sector have essentially been in the nature of disposal of residuals created due to low per capita income and low consumption demand of certain essential commodities." In other words, the inequalities among regions and castes which the Green Revolution failed to tackle made the surpluses for export possible. It should be noted that the increased irrigation, chemical fertilizers and pesticides also exacerbated environmental problems, as HYV technology was often inappropriate for Indian ecological systems (Reeves and Cohen 1992, 44).

In the national market, agricultural prices were driven down by increased production. Even the non-HYV strains and the nutritious crops which can be grown on poor land and are less susceptible to climatic variability became less profitable to cultivate as they lost ground to competition from the HYV crops, establishing a pattern of steady decreases of returns to the small nonparticipating farmer. This also contributed to geographic disparities since only some kinds of land were suitable for Green Revolution cultivation. This process undermined the income that poor agriculturalists could obtain in the market.

Three visible categories of poor farmers were created during the Green Revolution: those who participated in the project; those who did not but produced rice and wheat; and those who did not do the latter and cultivated crops not addressed through the project. All received less income from the sale of their crops. In the first two groups, the sudden increase of HYV grains in the market dropped the sale price of those grains, whether or not they were HYV (the market makes no distinction). The third group suffered as their produce became comparatively more expensive.

Impoverishment and agricultural displacement can be usefully analyzed using Amartya Sen's (1981) entitlements theory. Entitlements are the total set of endowments which can be exchanged for commodity bundles, including products such as food. This makes it possible to see hunger as not only the result of food availability decline due to drought and other disasters, but also as a marketdependent phenomenon linked to impoverishment-rising food prices, unemployment, ecological degradation, insufficient wages, inflation and terms of trade for peasants. This gradual and extensive process whereby people are stripped of their exchange entitlements to consumption resources shapes their vulnerability.

What this period overwhelmingly witnessed was the proletarianisation and entitlement loss of the small farmer and the landless agricultural worker as well as the overt "increase in the number and proportion of landless households, growing concentration of land and assets in fewer hands, and widening disparity between the rich and poor households" (Dasgupta in Gillespie and McNeill 1992, 39). Also, food production became divorced from nutritional concerns through the loss of crop diversity and the access of the poor to agricultural produce, increasing the risk of mal- and undernutrition.

Likewise, the increasing polarization of wealth and resources within the agricultural sector is directly linked to increased levels of poverty and the related inability to purchase food in sufficient amounts and of adequate nutritional quality. Even though India is widely regarded as the main national success of the Green Revolution, as Gillespie and McNeill (1992, 39) note, "increases in agricultural productivity were accompanied not only by increases in food production, but also by an increased risk of undernutrition for people within certain social groups."

\section{Rural Impoverishment and Displacement}

This vulnerability is vital to understanding the link between the Green Revolution and agricultural displacement in India. The technological inappropriateness of the Green Revolution displaced multitudes of small producers from their land and from their previous positions as producers. Such displacement is indirect in that it does not involve eviction; it is mediated by market prices and involves a choice that the family has to make about the nature of its livelihood. But it is a primary displacement effect in that it occurs within the sector in which the technology is introduced, i.e. agriculture. The displacement of poor cultivators is thus primary but indirect.

The factors behind landlessness and displacement are the decreasing returns on production-initiated cycles of borrowing and subsequent inability to pay creditors and the gradual stripping of entitlements through the sale of endowments, such as land and livestock, in order to meet basic needs. As Alvares notes, the aftermath of the Green Revolution has been marked by increased social inequity: "One of the forms this took was land alienation ... the displacement of tenants, marginal and small farmers by richer peasants. The Green Revolution effectively drove them into indebtedness" (Alvares 1994, 44). Although 
biotechnology indicates the creation of employment, this did not materialize to the point at which these workers could be permanently absorbed.

A more conservative estimation of the situation is offered by B. P. Singh $(1988,21)$, who notes that the consistent absence of opportunity to overcome the constraints imposed by low agricultural profitability and small land parcels leads to pervasive insecurity, inducing migration out of rural areas. Also, since the nature of agriculture implies seasonal labour, those who did find work had to rely on local agricultural labour markets and became exposed to its insecurities. If work could not be found locally, farmers usually migrated to the food surplus areas in hopes of finding work. The displaced farmers who could not find employment generally chose to migrate to urban areas where food subsidization programs, food distribution systems and food aid were in effect.

The increased risk associated with the cultivation of HYV crops and the loss of crop diversity within production do not in and of themselves inevitably lead to displacement; the outcome depends not only on the economic relations of production, but also upon the social context within which those relations occur. As Krimgold notes, "a disaster is a crisis situation that outstrips the capacity of a society to cope with it" (Anderson and Woodrow 1993, 133). Ostensibly, insecurity occurs within a context lacking in comprehensive government policies and redistributive systems.

It is also important to remember that vulnerability is not a sudden phenomenon; insecurity deepens over an extended period of time. It implies not only the inability of individuals to accumulate sufficient exchange entitlements, as mentioned earlier in this paper, but also the inability of communities and geographic areas to do so. Communities have intrinsic adaptive social relations which prevent or at least mitigate the impact of crises; growing economic risk and displacement of members represent the stifling of these systems to function ad- equately. The concept of flexibility under stress is also important here: "The ability to move; a choice in types and varieties of cash and subsistence crops; a choice of markets for crops or livestock in a drought ...; alternative ways of making money ...; and government insurance schemes" (Wijkman and Timberlake 1984,31) are also mitigating factors in the severity of vulnerable circumstances. Changing economic activity and migrating are thus not only effects of displacement, but also coping mechanisms.

When one considers the ramifications of the Green Revolution, the issue of displacement within the agricultural sector is not usually addressed. This is the less obvious consequence of socioeconomic insecurity if one considers displacement to be the manifestation of long-term vulnerability. The Green Revolution, despite its honoured place within development discourse, exacerbated inequities in agricultural production to the point that poverty, hunger and rural-urban migration increased among poorer agriculturalists.

In development discourse, vulnerability to the loss of land, to hunger, and to unemployment is generally reduced as economies "expand and diversify." However, the Green Revolution increased monocropping and introduced participating farmers to volatile global market prices and the risk associated with export-oriented agriculture. Land alienation and the proportion of the landless among agriculturalists increased substantially (Field 1993, 15-16). These consequences are usually hidden within the aggregate economic growth statistics by which development measures its success. In a single sweep, the harmful effects of development are discursively erased. As witnessed in the Green Revolution, the intensified suffering of the poor is traded for economic development for the higher strata of society. According to Alvares (1994), this phenomenon illustrates the allocation of economic and social resources to a vague notion of national development instead of to the subsist- ence needs of the people, highlighting the often diametric opposition between economic progress and basic needs.

\section{Irrigation, Deforestation, and Displacement}

The displacing effect of the Green Revolution also carried over into non-agricultural sectors such as tribal subsistence economies. The colonial "wastelands," as Vandana Shiva (1995, 210) notes, were productive lands, providing basic nourishment to the millions of subsistence agriculturalists and tribals in India as well as landless peasants migrating from overcrowded open field villages. Thus, the relationship of these areas to the Green Revolution is also significant. Not only did the forests accommodate the displaced farmer, they also lost ground to technological requirements of the Green Revolution. To quote at length:
... with the onset of the so-called Green Revolution, farmers in many parts of India switched to a new mix of agricultural technologies which in fact reduces their dependence on for- est resources. With the state provid- ing water, electricity, fertilizers and machinery at highly subsidized rates, the country's landscape has been dotted with pockets of fossil fuel agriculture, and the production of food and other cash crops for the urban market. Ironically, while chemical agriculture has (for its prac- titioners) reduced dependence on living resources, it has at the same time provided a powerful impetus for the destruction of forests through the construction of large dams for irrigation and power generation. (Gadgil and Guha 1993, 222)

In contrast to the previously described process of primary indirect displacement, the displacement occurring in "wastelands" and forests is secondary but direct. It is secondary in that the displacement occurs in a sector other than the one in which the technology is introduced. The Green Revolution is introduced to agriculture, but it has effects outside the agricultural sector. Displacement is direct in that hydro and irrigation projects involve in the first instance actual evic- 
tions of local people or prohibitions on their uses of forests and wastelands and thus direct restrictions on their livelihoods.

Both tribal and persons displaced from agriculture are becoming increasingly vulnerable as forests are reconceptualized as economic resources to fuel development. Instead of being seen for what they are to the peasant and the tribal person, they are regarded for what they could become to the government, by being exploited for the purposes of development (Alvares 1994, 211; Shiva 1991). The process has been occurring as available agricultural land is shrinking on a per capita basis (Venkateswarlu 1987, 91), thereby increasing the need for more intensive agricultural development. This intensiveness involves an even greater amount of irrigation and utilization of other Western methods and leads to increasing conflicts over water resources (Shiva, 1991). It is a process that reveals the nature of development: it begets more development.

\section{Socioeconomic Polarization}

During times of crisis, not everyone is placed at risk. Factors such as status, class, wealth, gender and access to information all determine the range of one's choices. They determine the intensified conflict over resources between those who are able to maintain their exchange entitlements to those resources and those who are not. By threatening subsistence production, development generates conflicts over resources and communal disharmony. The conflict is between the customary endowments and entitlements regarding the use of the resources and their moral legitimacy, on the one hand, and the legally encoded rights in the context of development and market relations, on the other.

It is the organization of the state and its relationship to development which either increases or decreases peoples' vulnerabilities. The interests that development serves as well as its dependence on the existence of replicable projects places local concerns at the margins of practice; development thus tends to aggravate rather than reduce vulnerability. This applies particularly to the employment of the new agricultural technology. Moreover, in the context of international economic relations, development projects aimed at ameliorating conditions in the South are often shaped to serve private Western interests. The effect again is to intensify vulnerability.

\section{Conclusion}

In spite of the development experienced during the Green Revolution in India and the success attributed to it, hunger is still rampant and is greater than at its onset in some regions and among many small cultivators. With its focus on large and mid-size farmers and the improvement of their conditions, it did not serve social justice. In fact, the Green Revolution had deleterious consequences for the rural poor. This occurred through two effects. Primary indirect displacement of poor agriculturalists resulted from lower prices for their produce and a lack of productivity improvements due to the unattainability of Green Revolution technology; the consequences were impoverishment, increased hunger, the forced sale of land and movement into other economic activities and often to other areas. Moreover, as the agricultural sector became more tightly bound to larger markets and their volatility, there was increased insecurity and further displacement. The second effect was the secondary direct displacement of those dependent on forest resources by the state's appropriation of those resources for modernized agriculture. The combined impact has been a divergence of living conditions and their security for those affected by the Green Revolution. This means that such polarization and the displacement that accompanies it is central to the debate on the implications of development in the South. When development is reconceived as a cause of social vulnerability, its rationale and approach must be reexamined. Social justice must be part of any justifiable conceptualization of development.

\section{References}

Alvares, C. 1994 . Science, Development and Violence. Delhi: Oxford University Press.

Anderson, M. B., and P. J. Woodrow. 1992. "Reducing Vulnerability to Drought and Famine: Developmental Approaches to Relief." In The Challenge of Famine, edited by J. O. Field, 131-46. West Hartford: Kumarian Press.

Byres, T., and B. Crow. 1988. "New Technology and New Masters of the Indian Countryside." In Suroival and Change in the Third World, edited by B. Crow, 163-81. New York: Oxford.

Chattopadhyay, B. 1991. Food Insecurity and the Social Environment. Calcutta: K.P. Bagchi \& Company.

Etienne, G.1988. Food and Poverty. New Delhi: Sage Publications.

Field, J. O. 1993. "Understanding Famine." In The Challenge of Famine, edited J. O. Field, 11-29. West Hartford: Kumarian Press.

Gadgil, M., and R. Guha. 1993. This Fissured Land. Berkeley: University of California Press.

Gillespie, S., and G. McNeill. 1992. Food, Health and Survival in India and Developing Countries. Delhi: Oxford University Press.

Mellor, J. R. 1992. "Green Revolution Reduces Hunger in India." In Hunger 1992, 42-49. Washington: Bread for the World Institute on Hunger \& Development.

Reeves, D., and M. J. Cohen. 1992. "Equity, Ecology, and Alternative Agricultural Technologies." In Hunger 1992, 44-47 Washington: Bread for the World Institute on Hunger \& Development.

Sarma, J. S. 1982. Agricultural Policy in India: Growth with Equity. Ottawa: IDRC.

_.. 1989. "Status with Regard to Production and Availability in Agricultural Surpluses for Export." In Indian Agro Exports, edited by F. S. Jasol, 151-55. New Delhi: Viva Photographers.

Sen, A. 1981. Poverty and Famines. Oxford: Clarendon Press.

Shiva, V. 1991. Ecology and the Politics of Survival. New Delhi: Sage Publications.

Shiva, V. 1995. "Resources." In The Development Dictionary, edited by W. Sachs, 20618. London: Zed Books Ltd.

Singh, B. P. 1988. Betrayal of Rural India. Delhi: B. R. Publishing Corporation.

Venkateswarlu, J. 1987. “Ecological Crises in Agro-Ecosystems." In India's Environment, edited by J. Bandyopadhyay, 91109. Dehra Dun: Natraj Publishers.

Wijkman, A., and L. Timberlake. 1984. Natural Disasters. Washington: Earthscan. $\square$ 